\title{
Op die spoor van my voorsate
}

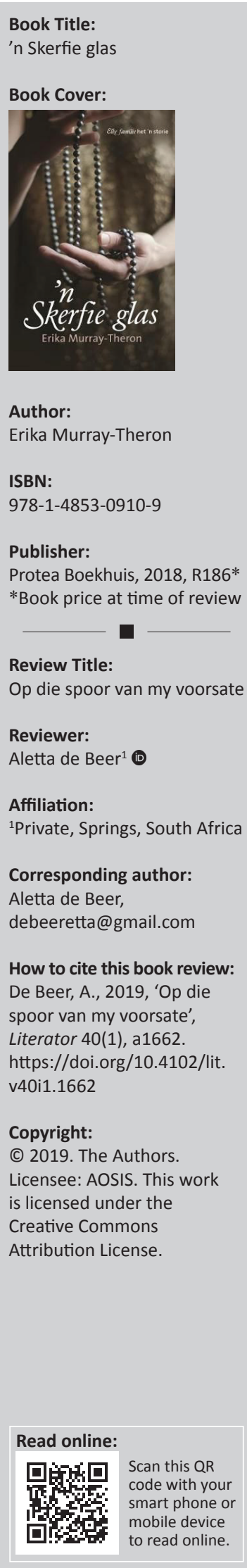

Erika Isabel Murray is op 01 Oktober 1941 op Greytown in Natal gebore. By haar pa leer sy 'n fyn aanvoeling vir en belangstelling in taal aan; hy was 'n taalonderwyser. Sy gaan onder onder meer skool aan Colenso Laerskool en Hoërskool Glencoe. Daarna studeer sy aan die Universiteit van Stellenbosch en behaal haar B.A.-graad met hoofvakke Afrikaans-Nederlands en Sielkunde, asook B.A.-Honneurs in Sielkunde, albei met lof.

Romans wat uit haar pen gevloei het, is onder onder meer: Wie is jy, Elizabeth? (1989), Die toubrug (1992), Vlegsel (1995), Blikkie sonder boom (1997), Die Mezzanine-klub (1998), Sê Maria (2001), Kaalvoet oor die berg (2001), Verblyf (2007), 'n Tapisserie met klein diere (2008) en Stippellyn (2014). Ook het sy 'n aantal kortverhale die lig laat sien.

'n Skerfie glas se buiteblad ('n vrou se sagte sensitiewe hande wat met donkergroen pêrels speel) getuig van 'n verhaal wat hoofsaaklik oor 'n vroulike karakter handel. Gedurende haar kleutertyd moes Issie Malherbe haar kleiner boeties help grootmaak. Terwyl sy die een boetie gedra het, het hy sy bottel (wat van glas gemaak was) laat val en 'n skerfie glas beland in Issie se oog. Jare later sou sy haar regteroog permanent begin skreef om die beskadigde iris teen lig te beskerm. In die roman ' $n$ Skerfie glas is die verhaal op die skrywer se lewensverhaal geskoei en word die outobiografie, skerfie vir skerfie, soos in 'n legkaart inmekaar gepas.

Voor in die boek is twee pragtige foto's, getrou aan die tyd waarin Issie se verhaal afspeel. Ook is daar voor in die boek 'n soort geslagsregister van 'n klompie mense vóór en ná Issie en Piet. Daarsonder sou die roman baie moeilik gelees het. Die leser moet telkens daarheen teruggaan om op hoogte te bly van wie dit is en watter rolle al die karakters speel.

In hierdie outobiografie soek die skryfster deur opdrifsels van papier na haar ouma Issie. Issie se pa ('n donker figuur) het haar Belle (sy mooie kind) genoem. Toe hy haar aan sy tweede vrou voorstel, noem hy haar Issie en Issie besef dat daar' $n$ afstand tussen haar en haar pa ontstaan het. Ten spyte daarvan het haar dapperheid dieper as heldedade gelê.

Op'n subtiele manier skilder die skrywer alle gebeurtenisse en lotgevalle van haar gerespekteerde familie en hulle sielkundige ontwikkeling, so lewendig dat die leser sonder moeite 'n prentjie van die gebeure en lewenstyl kan vorm. Hierdie verhaal is die verhaal van die skryfster se familie, van haarself en uiteindelik die Afrikanervolk. Politiek word op dieselfde subtiele wyse in die roman ingewerk. Murray-Theron se familie-lotgevalle ontvou deur baie jare op verskillende plekke soos Tulbagh, Wellington, Johannesburg, Pretoria en Nylstroom en dit kry daarom ook in die roman 'n plek. Issie se ouma Belle beleef groot smart op Tulbagh en Wellington. Te midde hiervan handhaaf sy 'n besondere lewenstyl.

Ouma Belle is dan ook die matriarg van die familie. Sy is beslis een van die sterkste karakters in die boek, maar sy boet nie haar sagtheid in nie. Haar hande het vir niks verkeerd gestaan nie. Haar wilskrag en pligsgevoel hou haar aan die gang. Sy het ses van haar elf kinders, asook haar man, aan die dood afgestaan. Sy word van die broosheid van die mens bewus toe haar dertien maande oue Albertus sterf. Wat sy nie verloor nie, is grasie en liefde. Nieteenstaande al die hartseer, sorg sy dat die meisies 'n goeie opvoeding kry. Bella is 'n sorgsame en liefdevolle ma en wanneer dit by geleerdheid kom, besonder opofferend. Haar familiekarakters is indrukwekkende en geleerde mense met ' $n$ goeie kultuuragtergrond. Murray-Theron vra haarself af hoe haar familie, wat Boere-adel genoem kan word, apartheid kon skep. Hulle was hardwerkende, eerlike, gelowige, ontwikkelde en belese mense. Waarom dan die regering van die dag, wat apartheid afgedwing het, ondersteun?

Lesers wat in politiek, die land se geskiedenis, sielkunde en die taal belangstel, sal beslis hierdie roman geniet. 